\title{
State Surveillance on the Internet- The Swedish Debate and the Future Role of Libraries and LIS
}

\author{
Simon HAIKola AND SARA Jonsson \\ Swedish School of Library and Information Science (SSLIS) at Göteborg University and \\ Högskolan i Borås, Sweden
}

This article contributes to what we hope will become a vigorous debate on Internet surveillance and privacy issues, ensuring that privacy issues will not be neglected in the future when political propositions on state surveillance are made. The relevant question to ask is not how to protect privacy at all costs, but how a balance can be found between the need of the state to know about its citizens and those same citizens' need for privacy from state intrusion. This paper explores the future role of the library pertaining to the issue of state surveillance. After a short introduction, we present the procedure and theoretical background for the article. The latter is grounded on Foucault's theory on discourse, power and the modern state. We then discuss our two main findings, and finally we relate those findings to the library and its future roles, and to library and information science research and teaching. We find one of these roles to be as instigator of and facilitator and forum for a healthy debate on surveillance and privacy issues.

\section{Introduction}

In this article we explore the discourse in the Swedish Riksdag on state Internet surveillance. [1] State surveillance is a highly topical subject, in recent years very much discussed in media as well as on political level. Since the attack on the World Trade Center on September 11 2001, and as a part of the subsequent "war on terror", states around the world have taken measures to increase the scope of their surveillance. However, while surveillance has been a topic of discussion, there is a discontent and anxiety in the field of information science that privacy issues are neglected when new propositions on state surveillance are made. With this article, we wish to increase the understanding of surveillance and privacy issues and to make a contribution to a debate; a debate that we hope to see grow and supply politicians with the knowledge to be able to make well-balanced and rational decisions on surveillance. [2]

\section{Procedure}

The material studied for this article was exclusively parliamentary publications, which includes documents such as government bills, reports and parliamentary bills. The texts chosen by us were analysed with a discourse analysis inspired by Foucault, where we focused on certain aspects such as relation between state and citizen, "conditions of possibility" (for Foucault, a discourse's "conditions of possibility" means a horizon of understanding that determines what makes sense to speak of in that particular discourse, certain presuppositions that allows certain statements to be made), etc. The documents studied were found by

Simon Haikola and Sara Jonsson were Masters students in Library and Information Science, Swedish School of Library and Information Science (SSLIS) at Göteborg University and Högskolan i Borås, Sweden. Address: Högskolan i Borås, The Swedish School of Library and Information Science (SSLIS), SE-501 90 Borås, Sweden. E-mail: simonhaikola@gmail.com and saraj80@ hotmail.com 
searching for various keywords and phrases, such as "surveillance AND Internet", on the Riksdag webpage. Each document found in this search process was manually assessed by us, as to relevance.

Obviously, the process of deciding which documents to deem pertinent and which not to is highly subjective. It has been a complex matter in our research, since what we do is in fact separating a narrow field within an encompassing discourse and establishing this as a separate discourse. That is, we take from "the state surveillance discourse" what we deem to be a part of the more narrow "discourse on state surveillance on the Internet". Hence, the subjectivity of the process of information gathering is important to stress, since it means that we as researchers partake in the forming of the discourse.

All this being said, we have defined one possible area of discourse, not saying that this is an absolutely accurate delimitation. Our purpose with the research was, as stated above, to observe how the Swedish Riksdag and Government relate to the new area of citizen communication and interaction that is the Internet. Our presupposition was that this new technology, evolving rapidly as it was in the early 1990s and growing increasingly in public use, was a phenomenon that the Swedish state [3] would have to decide how to relate to, how and if to control and supervise. We had an understanding of the modern state as an entity founded on and largely dependant on surveillance, and we aimed to examine how this aspiration to supervise became apparent in the discourse on Internet surveillance, if it did. This understanding of the surveillance nature of the state was grounded on Foucault's theories on the modern state, presented below.

\section{Theory and method; Foucault}

As stated above, our theoretical understanding of our research object comes from Foucault's theory on discourse, power and the modern state. Foucault says about power, that it is not negative and only about denying and refusing things. Neither is it something that is diffused in a simple, one-way directed, hierarchical relationship. Rather, it is something that permeates all of society and every human relationship, something non-tangible that works in every direction, all the time. That is not to say that power cannot be made the object of research (obviously Foucault thought it made a suitable research object), because power is still something that can be understood and studied. This is not in the sense that every power relation is the result of a directing, active subject, but because power is always exercised with purposes and goals. The rationality of the power, which is what interested Foucault, can be seen by examining the rationality in methods that are often very explicit on their level (Foucault 2002a).

Foucault's perspective on power means that power cannot be seen as the subjugation of a weaker part by the stronger, since there can never be a human relationship without there also being power. This understanding of power could be interpreted as giving cause to cynicism and determinism; indeed it is a point in the thinking of Foucault that has drawn much criticism. However, it is important to point out that Foucault considered resistance to power to be equally everpresent. In fact, power and resistance are mutually dependent on each other: wherever there is power, there is also resistance to that power. In an interview, his view on the relationship between power and resistance is expressed as: "less of a face-to-face confrontation which paralyzes both sides than a permanent provocation" (Foucault 1982 , s. 222). (Admittedly, this line of thinking could just as much be considered as reason for cynicism and determinism. If resistance is always conditioned by the power, then one could easily draw the conclusion that effective opposition is futile. That bleak outlook is not a necessary conclusion from Foucault's reasoning, however. The fact that resistance is conditioned by power relations does not in any way mean that it is futile. Indeed Foucault himself did not consider opposition in the form of, for example, social movements to be vain attempts at resistance.)

Power, according to Foucault, is very much about deciding what to talk about and what not to talk about. Obviously, if power is everywhere it is not something that, say, a king or ruler or a politician, can claim exclusively as his or her own. The relatively powerful positions in society are just that, power positions, because they are dominant in deciding what is talked about, what is put on the political agenda. Here, we connect to Foucault's theory on the discourse. The discourse, according to Foucault, is a specific way of talking 
about something, an area of statements for which a special set of rules (not necessarily formulated as rules, although they can be of course) apply. The discourse determines how and about what someone can speak. Thus, the discourse is limiting and controlling, it limits and controls its subjects. Within the discourse, there are a limited number of positions to speak from. Power relations work in and through the discourse; while the discourse is determined by power relations it also reconstitutes these power relations (Foucault 2002b, 1993).

Foucault devoted a great part of his work to the historic development of the modern state, and as a part of that development the birth and growth of liberalism and, more recently, neo-liberalism. He identified a specific power rationality as fundamental to the modern western state, namely the rationality of discipline. This power rationality aims to find out as much as possible about people, their behaviour and their habits, and to direct their actions according to certain patterns. This will be done, while at the same time people are acknowledged to be autonomous, individual subjects (Foucault 2003).

According to Foucault, western societies during the $18^{\text {th }}$ century ceased to be societies based on punishment as the rationality for power, and developed into societies of discipline instead. This means, that the political power is no longer exclusively negative, striving to punish, to remove dangers, to fight social unrest etc. The new power that expands as fundamental principle of the state and the government, is positive, in the sense that it seeks to direct the actions and lives of its subjects, the citizens, with the purpose of attaining highest possible efficiency. This purpose - efficiency - is crucial, since it is incompatible with a negative, punishing power. In order to be able to control the people in this new way, the state must know as much as it can about them; hence a premier goal of the state becomes a surveillance that encompasses all of society (Foucault 2003).

The disciplinary power rationality brings about the birth and rapid growth of techniques for classifying, mapping out and diagnosing people. Modern science consists of a rich flora of discourses pertaining to the question of what man "is", who is sick, insane, abnormal and so on. Thus, there is a process of individualisation of people that at the same time disciplines the same people into certain behaviours. The discipline penetrates society, all the time, so that the individual also disciplines herself, she internalises the discipline. This also means, of course, that the new subject - the individual - does not really exist in a relation of opposition to the state and its will to know and to govern. Rather, the individual is created as subject by the disciplinary aspirations of the state. The individual as we know it becomes just that, an individual, on terms conditioned by the power and the new science of man (Foucault 1982, s.214ff).

So we have established that a new type of power - a rationality for power - that is a disciplinary power leads to a process of individualisation. Also that a way of exercising this power, that is, a method this power uses to apply itself upon reality, is surveillance. To explain the principle behind this new ambition to supervise that is fundamental to the modern (western) state, Foucault uses the metaphor of Bentham's Panopticon. This architectonic idea for a prison was so constructed that every intern could be supervised every second of every day by a single guard, while the watching guard could not be seen by the interns. The idea is as ingenious as it is chilling, bringing to mind the picture of an all-seeing, omnipotent, invisible eye. In its theoretical completion, Panopticon actually renders the physical presence of a watching person superfluous, since the mere thought of being observed at all times will make the interns discipline themselves. Hence, Foucault manages to capture his theory of the disciplinary society quite brilliantly in this single, suggestive metaphor. It holds the picture of a society where the individual is "domesticated" by self-discipline, and where the guard/state supervises every aspect of social life. [4]

\section{The progression of the discourse; polarization and expansion of boundaries}

As we get a grip on the discourse in a larger perspective, having studied it since "the beginning," in a sense (see note 1) and following it through the change of government - from a long period of social democratic rule to the right-wing alliance - in 2006/07, we can see that there are two phenomena that stand out as characteristics of the discourse so far. These are a polarization of positions within the discourse, and an expansion of the discourse's boundaries. 
The discourse, as we have defined it, has its genesis in the Riksdag session of 1994/95, but the first couple of years are rather quiet and, in our interpretation of it, hesitant. By this we mean, that the discourse has yet to become established, as Internet becomes a known social phenomenon and made familiar to politicians. This hesitancy results in a relative lack of texts and in the few texts that actually exists, a lack of a clear understanding of "reality" and clearly formulated suggestions for state action. These early texts usually express a will for inquiries and more knowledge of the issues. In the session of 1997/98, as the discourse becomes established, we see a polarization of positions. On the one side, we have a "surveillance position", constantly arguing for maintained and often increased surveillance authority for the state. On the other side we have a "privacy position", arguing for the importance of attentiveness to privacy issues, and respect for privacy. While the discourse after $1997 / 98$ is not totally devoid of nuances, the rigidity of this dual relationship is indeed a striking feature: one position arguing for the need of surveillance, and the other arguing for the need of prudence.

This is in fact a quite complicated issue, what does constitute an increase in surveillance authority. There is an argument that the state by transferring old legislation authorizing surveillance to a new area such as the Internet, merely maintains its surveillance authority. However, one might as well argue that this action constitutes an increase in surveillance authority, by stressing the fact that it does mean surveillance of an area of social life that was not before supervised (admittedly, because it did not exist before). However, it is even more complicated than this. When dealing with new technology such as the Internet, there is no objective answer to what is an adequate transfer of old legislation; the wire-tapping of a telephone can never, of course, have an exact equivalent in the online environment. One can argue that the reading of an e-mail, for example, is the equivalent, but it can never be the same thing.

Both positions in the discourse take a dual stance, in the meaning that they always admit to the validity of the other side's argument. For example, a politician arguing for increased surveillance will never fail to stress also the value of privacy; conversely, the politician that speaks about the threat to privacy inherent in state surveillance, will admit there is a need for state surveillance. Knowing this, it would be easy to imagine the discourse being a stalemate, with no real advances being made from either side (to use some military language). However, this is not at all the case. There is a continuous expansion of the discourse's boundaries, and this expansion occurs unilaterally on the terms of the surveillance position. This is indeed an interesting phenomenon: while the struggle within the discourse, and the relation between the two positions, looks very much the same from the period of polarization in 1997/98, the boundaries are being continuously pushed forward. By this we mean, that the scope of surveillance proposed and discussed is constantly widened.

About this two things can be said. First, that the discourse works very much like Foucault said, as a field where there is a limited number of positions to be spoken from, and indeed a limited way to speak of things as well as a limited number of things to speak of. Secondly, that we see the onesided character of the boundary expansion as a result of the privacy position's status as a position of resistance. The surveillance position is the dominant position, and the privacy position emerges in opposition to that. By this it is also limited, as it is conditioned by that which it is resisting. In other words, because it opposes the surveillance position, the privacy position partakes in the discourse on terms decided by the former. For every advance made by the dominant position, the position of resistance will resist, but the advance cannot be undone.

This is also very much in line with the thinking of Foucault. Firstly, how what is spoken about, what is made into discourse, becomes part of the discourse (what is not spoken about is not part of the discourse, which is of course equally important). Secondly, how something is conditioned by something else, and limited by this.

The expansion of the boundaries is continuous, but it gains momentum from the parliamentary session of 2002/03. From this point on there is a marked increase in the attempts to increase directly the scope of state surveillance. A part of this process is the reinforcing of the threats that are used to motivate the need for increased state surveillance. Vague but powerful terms such as "organized crime" and "international terrorism", begin to feature heavily, often reinforced by more 
adjectives such as "ruthless" and "growing". Again, the limited and conditioned position of those speaking for the value of privacy becomes apparent, as there is no real or effective attempt to question these threats. There can be no doubt that the Swedish discourse at this point, with great threats painted with broad strokes, is an excellent breeding ground for proposals increasing state surveillance.

What we have said so far about the resistance within the discourse, should not be taken to mean that there is a lack of people within parliament that have a real desire to oppose the attempts to increase state surveillance. Rather, we see it as a symptom of the limiting function of the discourse. We see, as just stated, that the discourse comes to be characterized by a reinforcing of threats. Also, we have found a simplifying "us-and-them" rhetoric being used by the surveillance position, where the situation is analyzed or at least described, as being about protecting us - the nation and the citizens against them - the criminals and the terrorists and so on. Together this makes for a very limiting environment for opposing voices. Very soon the threats and this line of reasoning becomes the norm, the terms one has to submit to in order to be able to speak within the discourse. A part of this is also the argument often used by the surveillance position, that the issue can be reduced to a matter of siding with the criminal or siding with the victim of a crime. Against such an argument it might very difficult to defend oneself. [5] Another argument used, that we interpret as facilitating the expansion of the borders within the discourse, is that the speed of technological development is so quick, that the state will simply have to "keep up" and apply new technology in surveillance, or the criminals and terrorists will get the upper hand.

Our examination in fact shows that the Government, so far in the history of the discourse, has always taken the position advocating maintained or increased state surveillance. This is regardless of political ideology; the largest labour-party Socialdemokraterna are pushing for surveillance until the change in government in 2006. The rightwing party Moderaterna becomes the largest party in the new conservative government, and having consistently advocated strengthened privacy (in line with the classical liberal accentuation of the individual's right towards the state) they now suddenly appear as one of the parties most dominant in the pushing forward of the boundaries, supporting the bill 2006/07:63 which is a proposal for radically increased state surveillance. Interestingly enough, we see here a change of positions - quite like the "castling" move in chess between Socialdemokraterna and Moderaterna, where they both more or less take over each other's rhetoric. Again, this is a testament to the validity of Foucault's theory on the discourse, with its limited positions.

\section{What does the discourse tell us?}

After having examined the discourse on state Internet surveillance in Sweden, we thus see a constant pressure for more surveillance and increased state control. That is not to say, that there is a lack of resistance to this process; on the contrary, the resistance is constant. However, the expansion of the boundaries is made exclusively on the terms of the surveillance position. We come to the conclusion that this is the result of the existence of such a power rationality as Foucault wrote about, which he claimed to be a rationality of discipline. This would seem to contradict those many verdicts that have claimed the Panoptic metaphor to be obsolete in the western state of today, heavily influenced as it is by neo-liberal ideology. When used in the limited sense as expressing a state largely dependent on the knowing about and surveillance of its citizens (which is what we think Foucault meant by the metaphor, as well of course, as the self-disciplinary aspect of the Panoptic scheme, which we as well see as still valid) we find it to be very valid indeed.

Neo-liberal ideology stresses that point which is fundamental already in liberal thinking, which is the supremacy of the individual. According to Barry Hindess, expert on political science, neoliberalism takes as a fundamental principle the idea of individual autonomy as a fact of nature, and therefore also a right given by nature, while this idea in liberal ideology is merely one possible perspective on individual autonomy (Hindess 1995). It has also been said that neo-liberalism means a change in rationality for the state, so that when the fundamental principle of state power becomes to make every citizen a consumer, there is no longer a basic need for extensive surveillance. 
So it would indeed seem that neo-liberalism clashes with the state's will to supervise. However, when looking at the western hemisphere of today, it would be hard to argue that state surveillance is declining. On the contrary, surveillance seems to be expanding in a time where neo-liberal doctrine dominates most other areas of social life. An obvious case in point would be the U.S., the place where neo-liberalism is probably the most firmly rooted, and where state surveillance has been increased significantly since $9-11$. The pattern is the same in most western countries, however.

Therefore it seems to be little value in focusing on the impossibility of uniting the idea of state surveillance with neo-liberal political ideology; the fact is the two do co-exist. To us, this speaks of the deep roots surveillance has in the modern western state, and how firmly established it is as a power mechanism of the state. It does indeed speak of a certain power rationality, by which the state becomes depending on surveillance for the preservation of its power. Because what we see is not the incompatibility of political ideology and the power mechanism that is surveillance, but the use of the latter to protect the former. That is, the state uses surveillance to protect the idea of the autonomous individual and to secure the goal of making citizens into consumers. [6]

Thus, if we explain the continued importance of surveillance for the western state with a fundamental power rationality, does this mean that it would be impossible to consider the development with increasing state surveillance in "the war against terror" a "trend"? Certainly not. Rather it shows, again, the fundamental importance of surveillance for the state. In times of uncertainty and insecurity, surveillance is the mean states reflexively use to protect themselves and their citizens. One could also argue, of course, that states use the feeling of anxiety among their populations in a rather cynical and manipulative way, to increase the scope of their surveillance. Either way, surveillance stands out as a fundamental power mechanism of the state. We should also comment that, although the threat of terrorism does indeed begin to feature heavily some time after 9-11 in the discourse, it is merely one of several threats that are used to argue for increased surveillance. That would seem to disprove the theory that the "surveillance trend" can be explained only by "the war on terror", it goes well beyond that context.

\section{The Swedish debate}

The arguments used in the Swedish parliamentary debate follow a very distinct pattern. While there is a fundamental agreement between opponents throughout the studied period that the need of privacy and the need of state surveillance must always be balanced against each other, so that neither is reduced to unacceptable levels, there is also a continuous reinforcing of the arguments on behalf of those advocating increased state surveillance. The basic line of reasoning remains pretty much the same through the period: the side speaking for increased surveillance argues mostly from a security perspective, claiming the existence of effective state surveillance as prerequisite for an effective defence against crime. The side speaking for the importance of a high level of privacy protection argues from a basic notion of privacy as something worth protecting.

On the face of it, there is no real disagreement between the two sides of the debate. Both approve of the basic arguments of the other side; those advocating increased surveillance admit privacy matters must always be taken into consideration, while those sceptic about increased surveillance acknowledge the need for some privacy reducing measures. However, as we follow the debate it becomes clear that it is the surveillance position that one-sidedly dominates, while the privacy position takes a defensive stand. As the former position reinforces its arguments the latter merely follows, repeating its motto that privacy is important and expressing worry about drastically increased state surveillance. In the process, as a result of its defensive stand towards the other side, the privacy position, it seems, is forced to acknowledge more and more of its opponent's arguments. There is no real questioning of the arguments used by the surveillance position, as it continues to expand the boundaries of the discourse.

Some of these arguments were noted above: the choice between siding with the criminal and protecting the victims of a crime, and the argument that the speedy technological development threatens the security of the citizens. Something can be said about both these arguments. The former is interesting, rhetorically not least, in that it blurs the boundaries within the debate between pro-privacy and pro-surveillance. Those advocating increased state surveillance sometimes claim that 
they are in fact the real protectors of privacy, in that they protect the privacy of the victims of crime, their privacy having been violated by the perpetrators of the crime. This makes for a tough battle for the privacy position, suddenly made out to be the enemy of privacy. The latter of the just mentioned arguments is used very often by the surveillance position. The basic argument is that technological development is moving with such velocity, that it threatens society as long as it is controlled in some way. New technologies for communication must be supervised, or they give criminals an advantage that the state may never be able to bridge. According to this argument, new technology can be a threat when used by criminals and terrorists, but in the hands of the state an effective weapon in the fight against crime and terror. Interestingly, this argument is reinforced in a rather distinct way in Government bill 2006/07: 63 , where it is proposed that the state be allowed to conduct surveillance in the specific purpose of obtaining information on new technological developments.

The argument about the rapid and threatening technological development is in line with a general trend in the reasoning of the surveillance position; the reinforcing of threats. The threats used in the debate to argue for increased state surveillance become increasingly more stressed and more frequent after the parliamentary session 2002/ 2003, and a number of threats are added to a growing list. The technological development is one of these many threats, and terrorism is another. In the process we notice that it becomes much more common for the surveillance position overtly to propose increased state surveillance, whereas the argument in the earlier days of the debate is based on the extension of already existing legislation to new communication technology. The threats are often as vague as they are powerful, such as "the heavy, organized crime," "the international terrorism," etc. The vagueness of the threats, we imagine, make it difficult for opponents to present an effective counter-argument (see also Flyghed 2005). The increasing and reinforcing of the threats is very marked in the just mentioned Government bill 2006/07:63, which includes a whole list of threats that necessitates increased state surveillance. Interesting to note in this text is that the scope of state surveillance has been drastically increased, so that state surveillance is designed to deal with both internal and external threats against Swedish citizens both in Sweden and abroad.

\section{Resistance and the future role of libraries and library and information science}

If we have seemed rather pessimistic in this article about the possibility of an effective resistance, that is certainly not our purpose. Nor is it our opinion that resistance is futile. What we have found to be a constant expansion of the discourse's borders on the terms set by those arguing for increased surveillance should not be seen as a pre-determined process. It is true, that the discourse so far has been dominated by one of the positions, but there is no real reason to assume that it must continue to be so. In fact, there is some evidence that suggest a change in the trend. Government bill 2006/07:63, which proposes drastically increased state surveillance, met with heavy resistance in both the Riksdag and the public debate, and it was deferred until later. This could indeed be interpreted as successful resistance to the surveillance position within the discourse.

We have seen that the resistance position so far has been conditioned by its status as just that, a resistance position, and that it has been limited by having to submit to the terms set by the opposing position. Although we do believe that the discourse is limiting "by nature," we are also convinced, supported by the results of our analysis, that an actual change in the discourse can be made by introducing new ways of speaking of things, new forms of critique. There is no reason to believe that the right to dictate the terms of the discourse must belong solely to the surveillance position. What is needed is a vigorous and intelligent debate on privacy issues, and it is here we see the future role of libraries in this issue. We will return to this shortly.

In his article The war on terrorism: consequences for freedom of expression and the integrity of library users, Stuart Hamilton identifies three measures governments around the world have taken in the wake of 9-11 in the attempt to fight terrorism, which are directed against and that influence information on the Internet. The first is the legislation on storing of data on Internet usage, including information on such things as web pages visited and addresses e-mailed. The second is what Hamilton calls "the online equivalent of wiretaps", that 
is the surveillance of individuals online. The third is the censoring of online information; governments will sometimes attempt to remove material considered sensitive or even shut down web pages that publish such material. In addition to this, Hamilton sees a general trend, outside the context of "the war on terror", of governments attempting to impose regulations on the Internet (Hamilton 2004).

All of these measures that Hamilton identifies can be seen as directly affecting the work of libraries (even if online surveillance of individuals is probably generally directed towards personal computers). We cannot expect libraries to be able to make an effective resistance to the government's attempts to control and supervise online information (indeed, we should not expect that all libraries will want to make such a resistance, some might well be more interested in aiding law enforcement agencies in the search for terrorists and criminals). Hamilton also writes, in another article, of the inhibiting effect the very existence of state surveillance on the Internet will have on individuals' information-seeking behaviour. People will change and censor their online behaviour when they know that someone might be observing them (Hamilton 2005). Of course, this reminds us of the Panopticon, and gives renewed and rather disappointing support for its continued relevance as a metaphor for the state of today.

Libraries that wish to protect the privacy of their users, and their right to have access to free information, can take measures to allow people anonymity on the Internet, and to inform them clearly about the existence of surveillance and/or censoring mechanisms. However, if the state is determined to expand its surveillance and control of the information, we do not see libraries as being able to make any significant form of opposition to that process. Instead we see the libraries' role for the future as instigators of and facilitators and forum for a healthy debate on privacy issues. Many commentators on information policy have in the recent years pointed to such a debate as something very much lacking from more or less every political proposition on increased state surveillance. The point is not, of course, that all surveillance is necessarily evil, but that privacy issues are not adequately dealt with when new legislation is made or proposed. As experts on the relevant issues, librarians will be able to play a very significant role in revitalizing the privacy debate. When such a debate exists, it will be likely to change the political discourse, thus making an actual and important difference.

So while we assess there is little or no space to manoeuvre for the individual library when legislation reducing privacy has been put in place, we deem the role of library and information science to be of great importance in the immediate future. There may be cases where libraries can bend the rules and interpret the laws from a privacy standpoint and in a more benevolent way; however they can never be expected to abandon the boundaries of the law in a willingness to protect the privacy of their users. This being the case, the importance of legislation on privacy matters being made on well-founded and rational decision-making becomes all the greater. The responsibility of seeing to this happening lies within the field of library and information science. Developments in recent years suggest that we cannot always rely on politicians to base their judgements on thorough research, so it must be up to the library and information scientist to make sure legislators are always supplied with the latest and most relevant findings on privacy matters. Today, when privacy has come under heavy fire with governments around the world attempting to increase the scope of state surveillance, it is of the highest importance that those who are experts within the field make themselves heard. Not only those employed within the academic field of library and information science are important here; there is also a great need to hear from library professionals whose expertise and experience from the professional field is highly valuable.

Far be it from us to suggest that privacy is an absolute good that can never be challenged. Of course, every society depends on its citizens giving up a certain amount of their privacy to the state - at least any form of society that most people would consider to be a good one. The state will always need information about its citizens in order to be able to implement health and pension programs, in order to keep them safe etc. The relevant question to ask is, therefore, not how to protect privacy at all costs, but how a balance can be found between the need of the state to know about its citizens and those same citizens' need for privacy from state intrusion. The question will certainly be answered differently by different 
people and by different societies, but it must be asked and it must be asked continuously, and it must be answered by experts.

\section{Notes}

1. It is in the 1994/95 parliamentary session that we first find parliamentary texts relating to that specific issue. That is, however, a truth with some modification. Firstly, the text we judge to be the first pertinent one (a Government bill), does not explicitly deal with Internet, but rather vaguely with "new technique". Secondly, one could convincingly argue that it is in fact impossible to make such a distinction between the discourse on state surveillance on the Internet, and the discourse on state surveillance.

2. This article is based on our Master thesis Statlig övervakning av internet - En diskursanalys av riksdagstryck 1994-2007 [State surveillance of the Internet - A discourse analysis of Parliamentary publications 19942007]. Göteborg University and Högskolan i Borås; Swedish School of Library and Information Science (2007).

3. In our Masters thesis, we use the term state as signifying politicians in Riksdag as well as Government. Given our theoretical framework it is a "natural" consequence to treat the state in this way, as a whole entity totally separated from the citizens. It is also something that facilitates our research, as we attempt to find which relationships between state and citizens are established in the discourse. We are aware, however, that it is a choice with some complications. It is over-simplifying, and in a way even misrepresenting, of reality. More common in sociological research is to make a distinction between state in the meaning Government on the one hand, and Parliament on the other. Indeed, our examination of the discourse shows that many politicians (from the opposition parties in particular) tend to identify with - and of course want to be seen as part of - the public, rather than the state.

4. A couple of reservations should be made about the Panoptic metaphor. Firstly, it should probably not be interpreted as Foucault saying that the western state strives towards a total surveillance of every inch of citizen's lives, at least not the state of today. Rather it is about a surveillance that encompasses all of society, that leaves no aspect of society unchecked. While not theoretically uninteresting, it is however of academic importance only whether the state does indeed strive towards a total surveillance, or merely a surveillance that is sufficient for it to be able to maintain its power. If we should make an interpretation of the view of Foucault in this matter, we would lean towards the latter. (For more on Foucault's thoughts on this question, and "the security state" among other things, we refer you to Gordon (1991)). Secondly, the metaphor should not be taken to imply a guard-prisoner relationship between state and citizen; it would be very far from Foucault to suggest such a thing, believing, as he did, that power relations were ever-present and not (inherently) about oppression. (It is of course up to each person what he or she makes of the Panoptic metaphor. If one thinks of the state as a prison guard, it makes sense to extend the metaphor to this aspect as well.) Thirdly, while the Panoptic scheme is very much in line with Foucault's theory of the self discipline of individuals in the modern state, we do not think he meant to suggest that it was the actual surveillance that caused this discipline, as is the case in the Panopticon. It is easy to think of Orwell's Big Brother state here, where citizens dare not do certain things as they are aware of a constant watching eye. However, we do not think Foucault had such a bleak notion of state surveillance, even though he certainly did not rule out the possibility of surveillance having such an effect in a limited sense.

5. Janne Flyghed (2005), professor in criminology at the University of Stockholm, claims this is a common argument in the surveillance debate, from those arguing for increased surveillance.

6. This is, again, very much in line with Foucault's thinking on liberalism and neo-liberalism as "governmentalities". For Foucault, it was futile to see them as ideologies that failed to apply themselves upon reality, and to focus on them as doctrines. He meant that liberalism has functioned historically as an instrument for the critique of reality, a reasoning of how to govern that continuously reinvents itself and therefore is able to survive and constantly reappear in new forms (Gordon 1991).

\section{References}

Flyghed, J. 2005. Brottsbekämpning: Mellan effektivitet och integritet. Kriminologiska perspektiv på polismetoder och personlig integritet [Fighting crime: Between efficiency and privacy. Crimonological perspectives on police methods and privacy]. Lund: Studentlitteratur.

Foucault, M. 1982. The subject and power. In: Dreyfus, H. L. \& P. Rabinow. Michel Foucault: Beyond structuralism and hermeneutisc, 208-228. Chicago, IL: University of Chicago Press.

Foucault, M. 1993. Diskursens ordning: installationsföreläsning vid Collège de France den 2 december 1970 [The order of the discourse]. Stockholm: B. Östlings bokförlag Symposion.

Foucault, M. 2002a. Sexualitetens historia: Viljan att veta. Bd. 1 [The history of sexuality: The will to knowledge 
Vol. 1]. Göteborg: Daidalos; Uddevalla: Mediaprint.

Foucault, M. 2002b. Vetandets arkeologi [The archaeology of knowledge]. Lund: Arkiv; Smedjebacken: Fälth \& Hässler.

Foucault, M. 2003. Övervakning och straff: Fängelsets födelse [Discipline and punish: The birth of the prison]. Lund: Arkiv.

Gordon, C. 1991. Governmental rationality: An introduction. In: Burchell, G., C. Gordon and P. Miller (eds.), The Foucault Effect: Studies in governmentality, 1-51. Chicago, IL: University of Chicago Press.

Hamilton, S. 2004. The war on terrorism: consequences for freedom of expression and the integrity of library users. IFLA Journal 30(3): 199-207.

\section{Editorial history:}

Paper received 30 June 2007

(as student contest paper);

Final version received 23 September 2007;

Accepted 1 October 2007.
Hamilton, S. 2005. Freedom of access to information, freedom of expression and cyberspace. An introduction to the theoretical concepts and practical obstacles facing libraries providing access to information via the Internet. Copenhagen: Department of Library and Information Management, Royal School of Library and Information Science/ FAIFE 2005.

Hindess, B. 1995. Liberalism, socialism och demokrati: Variationer på temat politisk styrning [Liberalism, socialism and democracy: Variations on a governmental theme]. In: Hultqvist, K. and K. Peterson (eds.), Foucault: Namnet på en modern vetenskaplig och filosofisk problematik [Foucault: The Name for modern scientific and philosophical problems], 71-85. Stockholm: HLS; Stockholm: Gotab. 